\title{
A lean thinking perspective towards K12 classroom design in Turkey
}

\author{
Gökçe Nihan Taşkın ${ }^{1}$ iD , Onur Behzat Tokdemir ${ }^{* 2}$ iD \\ ${ }^{1}$ Middle East Technical University, Department of Architecture, Ankara, Turkey \\ ${ }^{2}$ Middle East Technical University, Department of Civil Engineering, Ankara, Turkey
}

\begin{abstract}
The learning environment has several significant influences on the education process. It affects students' motivation, attention and active participation, student-teacher interaction, and lesson plan. In that sense, classroom design is a critical concern to improve the quality of education. Classroom design has many parameters that should be taken into consideration simultaneously. A holistic perspective on all parameters and a systematic process is required to increase the quality of the design. This study aims to guide designers, eliminate mistakes, and improve the quality of classroom design by scrutinizing the required data and suggesting a methodology for the design process. The study focuses on the design of K12 classrooms in Turkey. Design inputs, requirements, and restrictions of K12 classroom design are investigated by using both universal and local resources. Collected data is categorized into four main groups which are, ergonomic needs of the students, organization of the classroom, optimum indoor quality requirements for the learning environment, and regulations of the Ministry of National Education of Turkey. A design methodology that covers the collected data in a holistic and systematic way is defined by applying lean thinking methods. It is an inductive methodology that starts from the smallest unit of the classroom, which is a desk and finalizes with the form and openings of the classroom. Also, an inquiry is suggested to evaluate design correctness. The study is concluded with exemplary drawings that depict the output of the data and the suggested methodology.
\end{abstract}

\section{Keywords}

Classroom design; K12; Lean thinking; Design methodology

Received: 26 August 2020; Accepted: 24 September 2020

ISSN: 2630-5771 (online) C 2020 Golden Light Publishing All rights reserved.

\section{Introduction}

The learning environment, in other words, features of a classroom, is an important factor for the quality of education [1]. Benedict et al. [2] stated that there is a direct relationship between the physical environment of the classroom and students' achievement. Ahrentzen et al. [3] argued that features of a classroom such as geometry and a total area of the classroom, ceiling height, façade openings, window types, and furnishing, affect both teacher's performance and students' success.

Ergonomics of the classroom furniture is significant for both students' health and learning performance [4]. Panagiotopoulou et al. stated that the dimensions of the desk are critical and should be relevant to students' body and ergonomic needs [5]. A classroom is a cluster of desks. Measurements of desks affect the area of the cluster they create so that they are input for the

\footnotetext{
* Corresponding author

Email: tokdemir@metu.edu.tr
} 
architectural design process for defining the form and dimensions of the classroom.

The seating arrangement is another main feature of the classroom. It affects student-teacher interaction and the procedure of the lesson plan or classroom activities. O'Hare [6] stated that different teaching techniques require different classroom layouts. Sztejnberg et al. [1] argued that teachers have different seating arrangement preferences for different classroom activities. In that sense, seating arrangement should be designed to improve the quality of the education and also should be flexible or adjustable enough for different lesson plans and class activities.

There is a direct relationship between students' position in the classroom and their grades [2]. This relation may be explained by student preferences. Marlowe et al. stated that students' preference for sitting on the front on in the backside of the classroom is mostly associated with their higher or lower academic performance, respectively [7]. However, Perkins et al. [8] showed that when students' preferences are eliminated, and they are placed randomly in the classroom, the same relation between students' position and grades is observed because of proximity. Students' proximity to the teacher is an important concern that affects students' performance. Holliman et al. [9] defined proximity in terms of the actual distance between student and teacher, where Sztejnberg et al. [1] suggested that it can be defined by the number of desk rows between teacher and student. In both ways, proximity is related to the seating arrangement and dimensions of the classroom, which should be controlled by the design of the classroom.

The aforementioned features of the classroom, ergonomics of the classroom furniture, seating arrangement, and indoor conditions are directly connected with the architectural design; they are either a design input or a consequence of the design decisions. Although a limited part of them can be flexible and adjustable, mostly, they are defined by design itself. O'Hare [6] stated that it is not enough to have movable classroom furniture to arrange a classroom as desired. Form, dimensions, and openings of the classroom should be designed accordingly to adjust the classroom environment for different activities in a successful way. Ahrentzen et al. argued that to be able to create a functioning classroom design, architects should understand the preferences and needs of teachers and students and base their design on this data [3]. In this study, a methodology is suggested to guide architects to deal with all requirements of classroom design simultaneously, eliminate mistakes, and improve the final design to contribute to education. The suggested methodology is constructed by applying lean thinking principles.

Lean thinking is originated from the lean manufacturing system of Toyota and applied to many industries as well as the construction industry to improve efficiency [10]. It is introduced to both design and construction phases. Lean design can be defined as application lean thinking principles to the design process in order to eliminate waste and improve value.

Hansen et al. argued that there are several approaches for lean design, such as streamlining the design process for efficiency, adapting design solutions to optimize construction phase focusing on users' needs and demands to add value to the design [11]. Freire et al. stated that lean design has three main concepts, which are conversion, value generation, and flow [12]. Conversation refers to outlining desired features of the end product and determining tasks or operations for achieving them. It is basically converting project requirements to design activities. Value refers to the quality of the project. Value can be achieved by eliminating defects and addressing all criteria that are desirable and demanded from the project [12]. Flow refers to structuring the flow of information for efficiency. It includes the collection of the required data for design, reworking on the data, and transferring the data from one design step to another. It directly affects the duration and performance of the design process [13]. The relation between value and flow can be analyzed by the value stream mapping (VSM) method. It is a diagrammatic map that depicts sources, operations, and end products of the process. It is beneficial to identify waste and 
improve the process. VSM can be adapted to the design process. It may clarify the flow of the information and enable the designers to control the process [14]. Ko et al. stated that VSM and a successfully defined flow could enhance the design correctness [15]. In their study, the design process is investigated into three stages, which are preliminary design, basic design, and detailed design. For each stage, VSM, flow, and design correctness are discussed separately. They defined design correctness as a metric for measuring to what degree the design meets the needs of user or application requirements. Questionnaires are suggested to calculate design correctness [15]. Table 1 shows an example of these questionnaires.

This study focuses on conversion, value, and flow to define the methodology. User demands are analyzed and converted to design requirements. Value is defined by investigating optimum qualities for classroom design. A systematic flow is constructed to adapt all these data to the design process and eliminate waste while improving quality.

Although most of the principles of classroom design are valid universally, countries have specific regulations for education environments. Similarly, principles alternate for different education levels. The content of this study is limited by K12 classrooms for Turkey. K12 refers to the first twelve years of education, which includes primary and secondary education. Regulations of the Ministry of National Education of Turkey are taken into consideration.

\section{User demands and design criteria for ideal classroom design}

Teachers' and students' needs and demands, as well as regulations of the Ministry, are investigated and categorized into four main sections: ergonomics, seating arrangement, indoor space quality, and regulations of the Ministry of Education.

Table 1. A questionnaire for calculating design correctness [15] (Template form)

\begin{tabular}{|c|c|c|c|c|c|c|c|c|c|c|}
\hline \multirow[b]{3}{*}{ Inspect Items } & \multicolumn{10}{|c|}{ Results } \\
\hline & \multicolumn{3}{|c|}{ Architect } & \multicolumn{3}{|c|}{ Structural Engineer } & \multicolumn{3}{|c|}{ Equipment Engineer } & \multirow[b]{2}{*}{ Remark } \\
\hline & Yes & Not Sure & No & Yes & Not Sure & No & Yes & Not Sure & No & \\
\hline \multicolumn{11}{|l|}{ Architect } \\
\hline Land-use concepts & $\square$ & $\square$ & $\square$ & $\square$ & $\square$ & $\square$ & $\square$ & $\square$ & $\square$ & \\
\hline Land area and building height & $\square$ & $\square$ & $\square$ & $\square$ & $\square$ & $\square$ & $\square$ & $\square$ & $\square$ & \\
\hline Natural environment investigation and analysis & $\square$ & $\square$ & $\square$ & $\square$ & $\square$ & $\square$ & $\square$ & $\square$ & $\square$ & \\
\hline Environmental impact analysis & $\square$ & $\square$ & $\square$ & $\square$ & $\square$ & $\square$ & $\square$ & $\square$ & $\square$ & \\
\hline Human environment investigation and analyses & $\square$ & $\square$ & $\square$ & $\square$ & $\square$ & $\square$ & $\square$ & $\square$ & $\square$ & \\
\hline Current land use situation & $\square$ & $\square$ & $\square$ & $\square$ & $\square$ & $\square$ & $\square$ & $\square$ & $\square$ & \\
\hline Spatial requirement analysis: Spatial content & $\square$ & $\square$ & $\square$ & $\square$ & $\square$ & $\square$ & $\square$ & $\square$ & $\square$ & \\
\hline Spatial requirement analysis: Spatial features & $\square$ & $\square$ & $\square$ & $\square$ & $\square$ & $\square$ & $\square$ & $\square$ & $\square$ & \\
\hline \multicolumn{11}{|l|}{ Structural engineer } \\
\hline $\begin{array}{l}\text { Foundation structure: Foundation geology } \\
\text { investigation }\end{array}$ & $\square$ & $\square$ & $\square$ & $\square$ & $\square$ & $\square$ & $\square$ & $\square$ & $\square$ & \\
\hline Foundation structure: Foundation type & $\square$ & $\square$ & $\square$ & $\square$ & $\square$ & $\square$ & $\square$ & $\square$ & $\square$ & \\
\hline Foundation structure: Roof structure & $\square$ & $\square$ & $\square$ & $\square$ & $\square$ & $\square$ & $\square$ & $\square$ & $\square$ & \\
\hline Foundation structure: Above-ground structure & $\square$ & $\square$ & $\square$ & $\square$ & $\square$ & $\square$ & $\square$ & $\square$ & $\square$ & \\
\hline Foundation structure: Underground structure & $\square$ & $\square$ & $\square$ & $\square$ & $\square$ & $\square$ & $\square$ & $\square$ & $\square$ & \\
\hline Seismic resistance structural design concepts & $\square$ & $\square$ & $\square$ & $\square$ & $\square$ & $\square$ & $\square$ & $\square$ & $\square$ & \\
\hline \multicolumn{11}{|l|}{ Equipment engineer } \\
\hline Equipment requirement analysis concepts & $\square$ & $\square$ & $\square$ & $\square$ & $\square$ & $\square$ & $\square$ & $\square$ & $\square$ & \\
\hline Electrical system concepts & $\square$ & $\square$ & $\square$ & $\square$ & $\square$ & $\square$ & $\square$ & $\square$ & $\square$ & \\
\hline Low-current equipment system concepts & $\square$ & $\square$ & $\square$ & $\square$ & $\square$ & $\square$ & $\square$ & $\square$ & $\square$ & \\
\hline Water provision and drainage system concepts & $\square$ & $\square$ & $\square$ & $\square$ & $\square$ & $\square$ & $\square$ & $\square$ & $\square$ & \\
\hline HVAC concepts & $\square$ & $\square$ & $\square$ & $\square$ & $\square$ & $\square$ & $\square$ & $\square$ & $\square$ & \\
\hline Emergency system concepts & $\square$ & $\square$ & $\square$ & $\square$ & $\square$ & $\square$ & $\square$ & $\square$ & $\square$ & \\
\hline Accessibility system concepts & $\square$ & $\square$ & $\square$ & $\square$ & $\square$ & $\square$ & $\square$ & $\square$ & $\square$ & \\
\hline
\end{tabular}




\subsection{Ergonomics}

Ergonomics of the classroom furniture is critical for children's health and their performance in learning. Floyd et al. noted that it is important to form the habit of sitting in the correct posture from an early age [16]. Improper furniture may cause musculoskeletal diseases and posture problems [4]. To prevent such symptoms, dimensions of desks and chairs should be appropriate for children's anthropometry. Castelluci et al. [17] pointed out anthropometric measures that are related to the school furniture and indicated corresponding furniture measurements for each anthropometric data. Table 2 shows a list of related measures.

Castelluci et al. [17] stated that, among these measures, seat height and depth are the most important ones for the children's health, whereas desk width and depth are mostly related to the functionality of the desk. They summarized 17 studies in which equations for classroom furniture dimensions are suggested, which are formed by using anthropometric dimensions. Some of the general principles that are followed in forming equations are;

- Seat height should not be greater than the popliteal height (distance from the underside of the foot to the underside of the thigh at the knees).

Table 2. Anthropometric measurements and corresponding school furniture dimensions [17]

\begin{tabular}{ll}
\hline $\begin{array}{l}\text { School Furniture } \\
\text { Dimensions }\end{array}$ & Anthropometric Measures \\
\hline $\begin{array}{l}\text { Seat height (SH) } \\
\text { Seat depth (SD) }\end{array}$ & $\begin{array}{l}\text { Popliteal Height (PH) } \\
\text { Bottom Popliteal Length } \\
\text { (BPL) }\end{array}$ \\
$\begin{array}{l}\text { Seat width (SW) } \\
\text { Desk width (DW) }\end{array}$ & $\begin{array}{l}\text { Functional criteria } \\
\text { Desk height (DH) }\end{array}$ \\
$\begin{array}{l}\text { Feat to Desk Clearance } \\
\text { (SDC) }\end{array}$ & $\begin{array}{l}\text { Thigh thickness (TT) } \\
\text { Desk Height (DH) }\end{array}$ \\
& $\begin{array}{l}\text { Popliteal Height (PH) } \\
\text { Elbow Height Sitting (EHS) }\end{array}$ \\
& Shoulder Height (SHH)
\end{tabular}

- Seat depth should be short enough to enable students to use the backrest of the seat and supporting their spine. Yet it should be long enough to support thighs.

- Seat width should be $10 \%$ to $30 \%$ larger than hip-width to provide both comfort and economical usage of the classroom area.

- Seat to desk clearance should be enough to allow leg movement while sitting.

- Desk height should be determined according to elbow height while sitting.

- Desk width and depth should be large enough to enable students to support their arms while writing and have enough space for classroom activities. Yet they should be plausibly small for using classroom area efficiently.

Panagiotopoulo et al. investigated anthropometric measures of 90 female and 90 male primary school students and suggest ideal seat and desk dimensions accordingly [5]. Table 3 shows the collected data, and Table 4 shows suggested measures for seat and desk.

\subsection{Organization of the classroom}

Seating arrangements and students' location in the classroom is critical for the education process. As discussed earlier, different teaching methods and classroom activities may require different seating arrangements. Some of the most used seating arrangements are; classical row and column, horseshoe, modular, and runner arrangements.

Traditional row and column arrangement is the most commonly used seating arrangement. [18]. This arrangement is suitable for listening, notetaking, lecturing, and examinations. It focuses all students' attention on one plane where the board is located. Interaction between student and teacher is the priority where the interaction of students with each other is neglected [19]. It is beneficial for individual studying rather that group works. Fig. 1 shows an example of a traditional row and column arrangement.

In horseshoe arrangement, students are directed to a central area of the classroom. This arrangement provides interaction between teachers and students and also increases interaction between students. 
Table 3. Anthropometric measurements of $2^{\text {nd }}, 4^{\text {th }}$ and $6^{\text {th }}$-grade students [5]

\begin{tabular}{|c|c|c|c|c|}
\hline \multicolumn{5}{|c|}{ Anthropometric measures of $2^{\text {nd }}$ grade students } \\
\hline & Minimum & Maximum & Mean & S. D. \\
\hline Height & 116.5 & 141.5 & 129.0 & 5.65 \\
\hline Buttock-popliteal length & 28.2 & 36.5 & 32.57 & 1.79 \\
\hline Knee height & 37.2 & 45.8 & 41.79 & 2.24 \\
\hline Popliteal height & 28.5 & 38.5 & 33.96 & 2.09 \\
\hline Elbow height & 34.7 & 50.2 & 43.92 & 2.64 \\
\hline Shoulder height & 13.3 & 22.9 & 18.22 & 2.17 \\
\hline \multicolumn{5}{|c|}{ Anthropometric measures of $4^{\text {th }}$ grade students } \\
\hline & Minimum & Maximum & Mean & S. D. \\
\hline Height & 127.5 & 158.0 & 140.97 & 6.30 \\
\hline Buttock-popliteal length & 30.7 & 40.0 & 35.52 & 1.93 \\
\hline Knee height & 41.3 & 52.2 & 46.15 & 2.52 \\
\hline Popliteal height & 33.0 & 40.8 & 36.89 & 1.90 \\
\hline Elbow height & 42.5 & 54 & 47.81 & 2.81 \\
\hline Shoulder height & 16.0 & 24.7 & 19.74 & 2.61 \\
\hline \multicolumn{5}{|c|}{ Anthropometric measures of $6^{\text {th }}$ grade students } \\
\hline & Minimum & Maximum & Mean & S. D. \\
\hline Height & 133.5 & 165.0 & 150.02 & 7.52 \\
\hline Buttock-popliteal length & 33.0 & 44.7 & 38.72 & 2.81 \\
\hline Knee height & 43.5 & 55.2 & 48.9 & 2.98 \\
\hline Popliteal height & 34.5 & 43.3 & 39.4 & 2.22 \\
\hline Elbow height & 41.5 & 58.0 & 50.8 & 3.40 \\
\hline Shoulder height & 15.8 & 27.2 & 20.9 & 2.47 \\
\hline
\end{tabular}

Table 4. Suggested dimensions for seat and desk [5]

\begin{tabular}{llll}
\hline & $2^{\text {nd }}$ grade & $4^{\text {th }}$ grade & $6^{\text {th }}$ grade \\
\hline Seat depth & $29 \mathrm{~cm}$ & $31 \mathrm{~cm}$ & $34 \mathrm{~cm}$ \\
& $90 \%$ of the students & $91.7 \%$ of the student & $83.3 \%$ of the student \\
Seat height & $32 \mathrm{~cm}$ & $34 \mathrm{~cm}$ & $37 \mathrm{~cm}$ \\
& $60 \%$ of the students & $56.7 \%$ of the students & $55 \%$ of the students \\
Desk height & Seat height $+20 \mathrm{~cm}$ & Seat height $+22 \mathrm{~cm}$ & Seat height $+23 \mathrm{~cm}$ \\
& $80 \%$ of the students & $73.3 \%$ of the students & $68.3 \%$ of the students \\
\hline
\end{tabular}

Therefore, it is beneficial for classroom discussions [20]. Another advantage of the horseshoe arrangement is; if the proximity is defined by the number of rows between teacher and students, horseshoe arrangement decreases proximity, which improves teacher and student interaction. On the other hand, it is not beneficial for group activities. Fig. 2 shows an example of a horseshoe arrangement. 

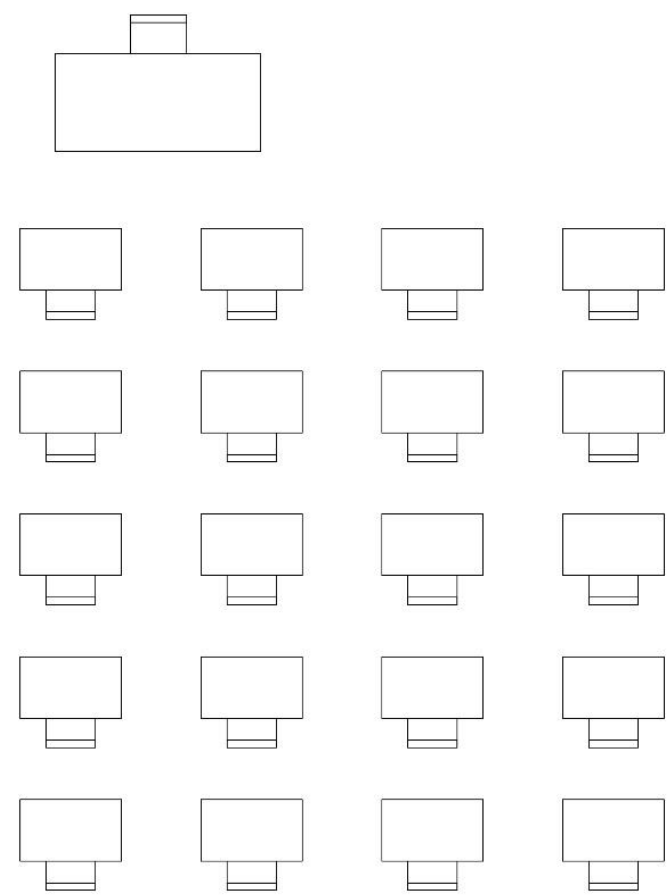

Fig. 1. Traditional row and column arrangement
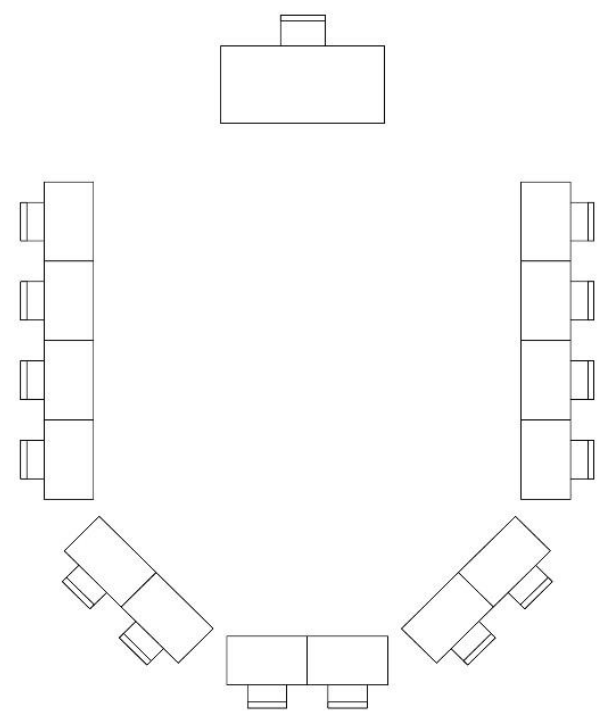

Fig. 2. Horseshoe arrangement

The modular arrangement consists of small clusters of desks. It maximizes the interaction between students and the most beneficial arrangement for the group works [20]. Inside the small clusters, students have a more private area in which they may express themselves with more confidence. However, in this arrangement, teacherstudent interaction is weakened. Since the classroom is divided into clusters, it is harder for the teacher to have the attention of all students and control the class. Fig. 3 shows an example of a modular seating arrangement 

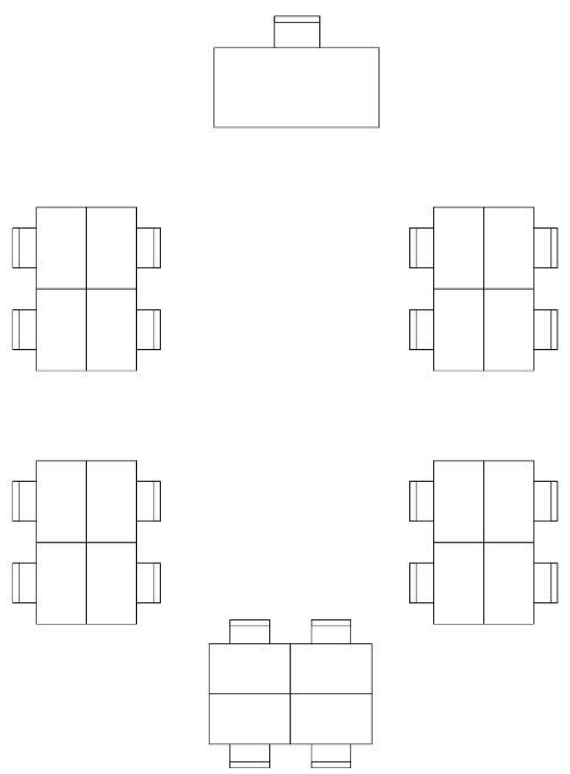

Fig. 3. Modular arrangement

All of the classroom arrangements have their own potentials and concerns. Scott-Webber stated that students prefer row and column arrangements for lecture-based courses, whereas they prefer horseshoe or modular arrangements for activitybased courses [21]. Teachers also prefer different seating arrangements for different activities. In that sense, an adaptive classroom environment is critical [1]. The seating arrangement should be adjustable, and it is not enough to have a movable desk and chairs to arrange the seating as desired. As it is pointed out earlier, the classroom is a cluster of desks. Dimensions and area of the classroom should be determined in a way that different seating arrangements can effectively be applied. Also, openings of the classroom, lighting condition and position of the board should be appropriate for all arrangements. Therefore, adaptive or fixed, the seating arrangement is an important concern for architectural design.

\subsection{Indoor space quality}

Indoor space quality is always a significant issue for the comfort and health of the occupants, especially for the spaces in which occupants spend a long period of time. Classrooms are one of these spaces. The amount of daylight and artificial lighting, indoor temperature, acoustics, and ventilation are important for students' health, comfort, and success. Ahrentzen et al. stated that both teachers and students are affected by perimeter openings, windows, ceiling height, and ventilation of the classroom [3].

Choi et al. noted that amount of daylight increases the motivation and the performance of the students [22]. Jago et al. investigated the effect of artificial lighting in classrooms and stated that it affects grades and achievements of the students and also can reduce the off-task behaviors of students. Illuminated surfaces should be selected carefully to achieve user comfort. In classrooms, desks should be illuminated well so that students can study comfortably, whereas; there should not be any glare on the board and projection panel [23].

Acoustic treatments are important for both eliminating surrounding noise and distributing sound inside the classroom in the desired way. In his study, Earthman pointed out that in the classrooms that are in the quiet neighborhoods, students have better academic performances in comparison with the classrooms that are located near to noisy vehicle roads [24]. Inside the classroom, the acoustic of the room should provide a comfortable space for lecturing and discussions.

Since students spend long hours in classrooms, indoor air quality is critical for their health. A high carbon dioxide ratio may cause health issues such as respiratory illness and chemical sensitivity [25]. Cash argued that temperature control and indoor air quality are two important features that affect the students' performance dramatically [26]. Mendel et $a l$. stated that there is a relation between the thermal conditions of the classroom and indoor pollutants, which affects students' health and comfort [27].

Natural and artificial lighting and ventilation, acoustic performance, and thermal conditions all depend on architectural design. The orientation of the building, façade openings, direction, insulation materials, acoustic performances of finishing materials, heating, and ventilation systems should be selected according to students' needs and comfort. 


\subsection{Regulation of ministry of national education}

To have a standard quality in every school and provide an ideal classroom environment for students' health and academic performance, the Ministry of National Education has a regulation for education buildings design [28]. Regarding classroom design, the regulation includes the following principles:

- Regarding the classroom furniture, it is stated that desks that are for two students should be used. In every classroom, there should be cabinets for students, a table and cabinet for teachers, an interactive board and projector, presentation boards, and hangers for coats. Cabinets and hangers may be placed on the corridor.

- Classrooms should be designed for 30 students. In primary school, there should be at least 1.6 $\mathrm{m}^{2}$ area for each student inside a classroom. For secondary and high schools, this area should be $1.85 \mathrm{~m}^{2}$ for each student. Additionally, there could be a $3-5 \mathrm{~m}^{2}$ storage area inside the classroom.

- The form of the classroom should be a rectangle. The exterior façade of the classroom should be on the long edge of the rectangle. The form should be suitable for different seating arrangements.

- Daylight should penetrate into the classroom from the left-hand side. Furnishing and door openings should be placed accordingly.

- The total window area of a classroom should be $25 \%$ of the classroom area.

- The floor to floor height should be 4 meters. If there is no basement floor in the building, floor to floor height should be 4.5 meters for the ground floor.

- In cold and temperate climates, classroom façades should face south-east, south, or southwest. In hot-humid climates, they should face south or south-west. In hot-arid climates, they should face east or west.

\section{Methodology for classroom design process}

The classroom design process includes interrelated design inputs and requirements; each of them is discussed in detail in the previous section. To cope with all these inputs in a holistic way, a systematic method is suggested by using lean thinking principles: conversion, value, and flow. This study aims to improve the quality of classroom design and to minimize the mistakes and project duration, as the main motto of lean thinking: "maximize value, eliminate waste." Firstly, conversion and value for classroom design are defined to explain what value is for a classroom design project, and then a systematic flow is defined to improve the process and eliminate waste. Finally, a questionnaire is suggested to calculate design correctness.

\subsection{Conversion and value}

Conversion refers to transforming the needs and demands of the user to design inputs. Teachers and students have both common and distinctive expectations and demands. Table 5 summarizes their needs and demands.

All these concerns should be converted to architectural design decisions. Some of them are related and refers to the same design decisions. Table 6 shows the conversion of all requirements and needs.

For classroom design, the features or qualities that improve academic performance and promote students' and teachers' health and comfort can be defined as value. The aforementioned design decisions should be taken with respect to these value criteria. Critical concerns for students' and teachers' health and comfort, which are discussed in detail, should be taken into consideration to add value to the design.

\subsection{Flow}

The design process consists of a series of interrelated decisions. Most of the time, it is not a linear process that every step only affects the following ones; instead, it is a complex process in which drawbacks and re-works occur. To minimize drawbacks and re-works, a systematic flow is suggested in this section. Throughout the flow, important concerns and requirements that must be taken into consideration are emphasized. 
Table 5. Teachers' and students' needs and demands in the classroom

\begin{tabular}{|c|c|c|}
\hline & Teachers & Students \\
\hline \multirow{3}{*}{$\begin{array}{l}\text { Distinctive } \\
\text { needs }\end{array}$} & \multirow{2}{*}{$\begin{array}{l}\text { Functional classroom environment to } \\
\text { monitor address and manage all class } \\
\text { efficiently }\end{array}$} & $\begin{array}{l}\text { Ergonomic needs, proper dimensions for the } \\
\text { chairs and desks }\end{array}$ \\
\hline & & Minimum proximity to the teacher \\
\hline & $\begin{array}{l}\text { Adjustable seating arrangements for } \\
\text { different teaching techniques and classroom } \\
\text { activities }\end{array}$ & $\begin{array}{l}\text { Functional classroom environment to follow } \\
\text { and participate in the lesson comfortably }\end{array}$ \\
\hline \multirow{7}{*}{ Common needs } & \multicolumn{2}{|l|}{ Enough desk/table area for studying/working } \\
\hline & \multicolumn{2}{|l|}{ Cabinet for each occupant } \\
\hline & \multicolumn{2}{|l|}{ Having enough space per each occupant } \\
\hline & \multicolumn{2}{|l|}{ Adequate daylight and artificial lighting conditions } \\
\hline & \multicolumn{2}{|c|}{$\begin{array}{l}\text { Acoustic treatments, elimination of exterior noise and comfortable lecture and discussion } \\
\text { conditions }\end{array}$} \\
\hline & \multicolumn{2}{|c|}{ Thermal comfort for health issues and academic performance } \\
\hline & \multicolumn{2}{|l|}{ Natural ventilation and a healthy indoor air environment } \\
\hline
\end{tabular}

Table 6. Conversion of requirements and needs to design principles

\begin{tabular}{ll}
\hline User Needs and Demands & Design Decisions \\
\hline Ergonomic needs, proper dimensions for the chairs and desks & Furnishing \\
Enough desk/table area for studying/working & $\begin{array}{l}\text { Selecting the type and dimensions of the } \\
\text { furnishing } \\
\text { Cabinet for each occupant }\end{array}$ \\
& Placement of the furnishing \\
\hline
\end{tabular}

\section{Minimum proximity to the teacher}

Functional classroom environment to monitor, address and manage all class efficiently

Functional classroom environment to follow and participate in the lesson comfortably

Having enough space per each occupant

Form and dimensions of the space

Defining the dimensions according to proximity and required form and area of different seating arrangements

Adjustable seating arrangements for different teaching techniques and classroom activities

Adequate daylight and artificial lighting conditions

Thermal comfort for health issues and academic performance

Natural ventilation and a healthy indoor air environment

\section{Orientation and perimeter openings}

Deciding the façade direction

Selecting window types, window sizes, sunshades

\section{Material selection and mechanical installations \\ Selection of finishing materials \\ Heating/cooling/ventilating systems}

Features that are related to each other are depicted with the VSM method. Fig. 4 shows the relation of the features which are dependent and how the information flows. This mapping shows that design decisions should start from the smaller components of the classroom and continue to a larger scale.

The first step of the process should be determining features of the desks and chairs, their dimensions, and locations in the class. 


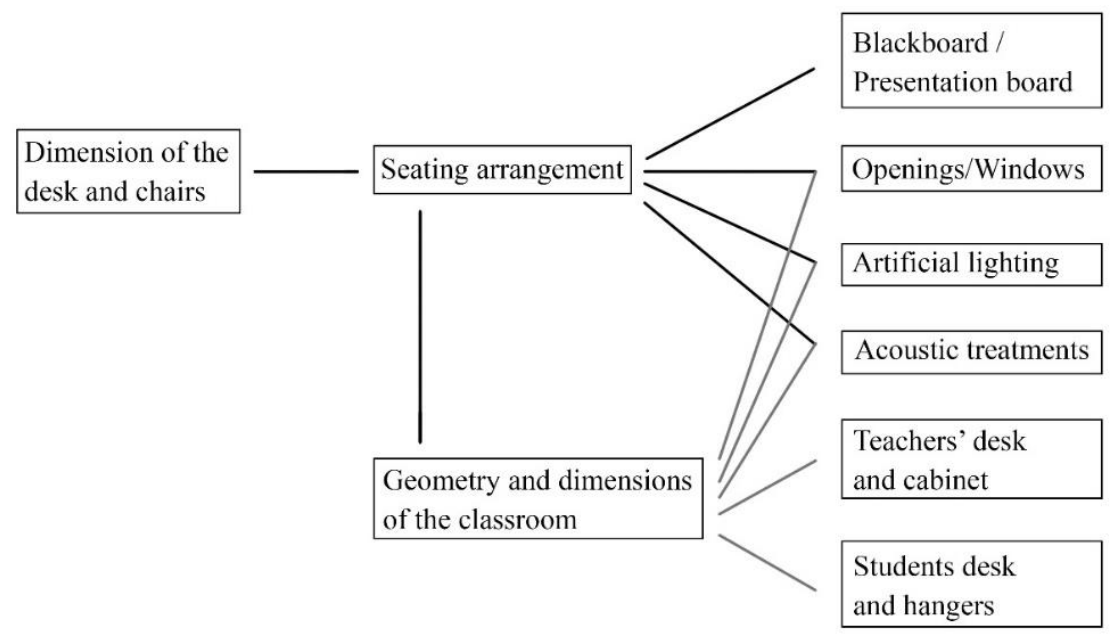

Fig. 4. Relation of the features information flow

Dimensions should be selected according to the anthropometric data. According to the regulation, each classroom should be designed for 30 students, and desks should be used by two students. Therefore, 15 desks should be placed in every classroom.

After defining the features of desks and chairs, seating arrangements should be taken into consideration. The most commonly used arrangement is a row and column arrangement. Fig. 5 shows three alternatives for placement of 15 desks by row and column arrangement. The regulation states that the form of the classroom should be a rectangle, and the exterior façade of the classroom should be on the long edge of the rectangle. The form should be suitable for different seating arrangements. Daylight should penetrate into the classroom from the left-hand side of the students [28]. In that sense, the exterior façade of the classroom will be on the left side for each drawing. Option 1 defines a rectangular area that fulfills the requirements regarding the form and daylight condition. Yet, this rectangular area may not be practical for other seating arrangements such as horseshoe arrangement. Another disadvantage of this option is proximity. Because of the rectangle's form, at the very back of the classroom, proximity may be problematic. Again because of the form, the area of the wall that board should be placed is limited. Option 2 also meets the requirements of rectangular form and daylight. In this option, proximity is better than option 1 . Desks define a rectangular area that is close to the form of a square in which different seating arrangements can be applied easily. Option 3 or other options that will be obtained by increasing the number of columns are not acceptable according to the regulation. The form of the classroom is still a rectangle; however, the exterior façade is on the short edge of the rectangle.

Once the area that will contain the desks is determined, dimension and location of the other components of the classroom, which are teacher's table and cabinet, students' cabinets, boards, and hangers should be determined. In this step, the rectangular form of class and the minimum total area should be considered. Students' cabinets and hangers may be placed on the corridor. For primary schools, it may be an undesired option since students are younger and require a more controlled environment and supervision.

After determining the floor plan layout of the classroom, mechanical installation, heating units, artificial lighting, and ventilation systems can be solved. The heating system and units should be determined according to the climate, insulation of the building, and insolation. To be able to use different seating arrangements in a successful way, artificial lighting either should be designed accordingly to suit all seating arrangements or should illuminate the space homogenously. 


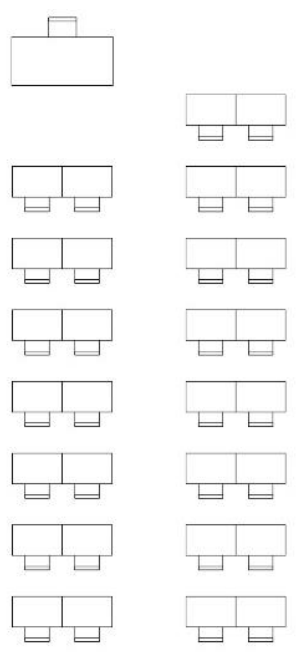

Option 1

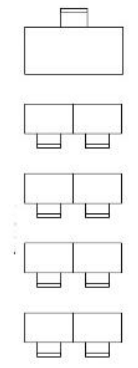

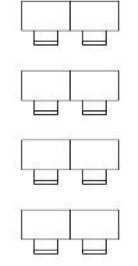

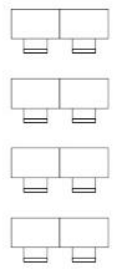

Option 3

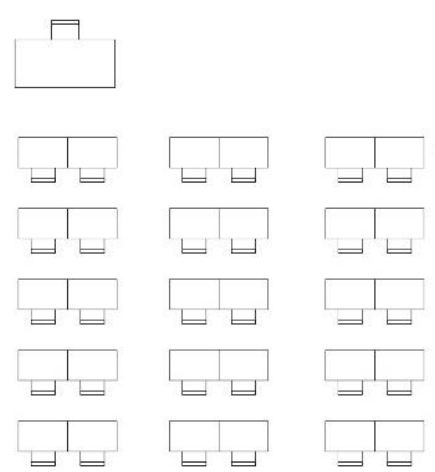

Option 2

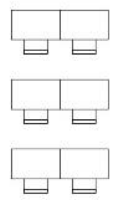

Fig. 5. Three options for row and column seating arrangement

For both cases, glare on the board should be eliminated. A suspended ceiling may be preferred for mechanical installations. The regulation states that the floor to floor height should be 4 meters. If there is no basement floor in the building, floor to floor height should be 4.5 meters for the ground floor. Suspended ceiling height should be determined according to this data.

Perimeter openings should be determined after the plan layout, and floor to ceiling height is set. According to the regulation, the total window area of a classroom should be $25 \%$ of the classroom area. Dimensions of the windows should meet this requirement and also should be determined according to the suspended ceiling height. Window type can be determined according to climate conditions and natural ventilation needs. Regarding the façade direction and climatic zone, sun breaks may be needed. Daily light should penetrate to the classroom to illuminate the desks for students' comfort. Glare on the board or projection board should be eliminated by adjusting windows location.

Finishing material selection can be the last step of the design. Selected materials should not harm students' health, provide acoustic and thermal comfort, and have an aesthetic quality.

\subsection{Design correctness inquiry}

Eliminating mistakes before they occur or before they affect the following stages is a critical contribution that lean thinking principles can add to the design process. Investigating the flow of the information and suggesting a methodology is beneficial in that sense. Furthermore, design correctness may also be taken into consideration to support a lean thinking approach. It is possible to 
evaluate design correction via an inquiry during or after applying the design methodology. Such inquiry may eliminate re-work, and the designer may proceed to the next stage with more confidence. Table 7 shows the suggested inquiry based on studies of Ko et al. [15]. Designers expected to evaluate each item and answer whether the design decisions or applications for these items add value to the project or not by selecting yes, not sure, or no options.

Suggested flow, including design correctness inquiry, is summarized in Fig. 6. The flow consists of 15 steps. On each step, a different design decision is questioned. Some of the design decisions depend on others, which are shown by arrows. Step 6 and 7 depend on the first five steps, which are depicted by red brackets and arrows. The flow is determined in a way that every step affects only the following steps, not the previous ones, to eliminate drawbacks and re-work. Questions are labeled with a blue and grey background. Decision criteria for the ones that colored in grey are occupants need for health and academic purposes. Decision criteria for the ones that are colored in blue are regulation of the Ministry of National Education [28].

\subsection{An exemplary case}

A hypothetical design case, in which the suggested flow is applied, is given in this section. 15 steps that are given in Fig. 6 are as follows;

Table 7. Inquiry for evaluating design correctness (Template form)

\begin{tabular}{|c|c|c|c|c|}
\hline \multirow[b]{2}{*}{ Inspect Items } & \multicolumn{4}{|c|}{ Results } \\
\hline & Yes & Not sure & No & Remarks \\
\hline Ergonomic requirements for desk & $\square$ & $\square$ & $\square$ & \\
\hline Ergonomic requirements for the chair & $\square$ & $\square$ & $\square$ & \\
\hline Adaptable seating arrangement & $\square$ & $\square$ & $\square$ & \\
\hline Teacher-student proximity & $\square$ & $\square$ & $\square$ & \\
\hline Practical blackboard/presentation board & $\square$ & $\square$ & $\square$ & \\
\hline Adequate total area & $\square$ & $\square$ & $\square$ & \\
\hline Adequate form and dimensions of space & $\square$ & $\square$ & $\square$ & \\
\hline $\begin{array}{l}\text { Adequate working area, cabinets, and hangers } \\
\text { for each occupant }\end{array}$ & $\square$ & $\square$ & $\square$ & \\
\hline Adequate total window area & $\square$ & $\square$ & $\square$ & \\
\hline Dimensions/types of perimeter openings & $\square$ & $\square$ & $\square$ & \\
\hline Daylight quality & $\square$ & $\square$ & $\square$ & \\
\hline Artificial lighting & $\square$ & $\square$ & $\square$ & \\
\hline Acoustic treatments & $\square$ & $\square$ & $\square$ & \\
\hline Ventilation systems & $\square$ & $\square$ & $\square$ & \\
\hline Thermal comfort & $\square$ & $\square$ & $\square$ & \\
\hline Finishing material selections & $\square$ & $\square$ & $\square$ & \\
\hline
\end{tabular}


Step 1: The classroom will be designed for $2^{\text {nd }}$ grade students. It will be occupied by 30 students.

Step 2: For the $2^{\text {nd }}$-grade students, the seat depth will be $29 \mathrm{~cm}$, seat height will be $32 \mathrm{~cm}$, and desk height will be $52 \mathrm{~cm}$, as suggested by Panagiotopoulo et al. [5]. Desk dimensions will be 60 by $40 \mathrm{~cm}$.

The required total area for the classroom classroom is $48 \mathrm{~m}^{2}$.

Step 3: Row and column and horseshoe seating arrangements will be used since they provide better control for teachers over the class.

Step 4: Students' cabinets and hangers will be inside of the classroom. $2^{\text {nd }}$-grade students may need a more controlled environment, as discussed. Cabinets will be located on the backside of the classroom, and the hangers will be located on the opposite wall of the exterior wall.

Step 5: Sunlight should penetrate to the classroom from the left-hand side of the students. Teachers desk, cabinet, and blackboard will be placed accordingly.

Step 6: To be able to use a horseshoe arrangement, the area that is occupied by the desks should be close to the form of a square. Considering also the other furniture, dimensions of the classroom will be 6 by 8 meters.

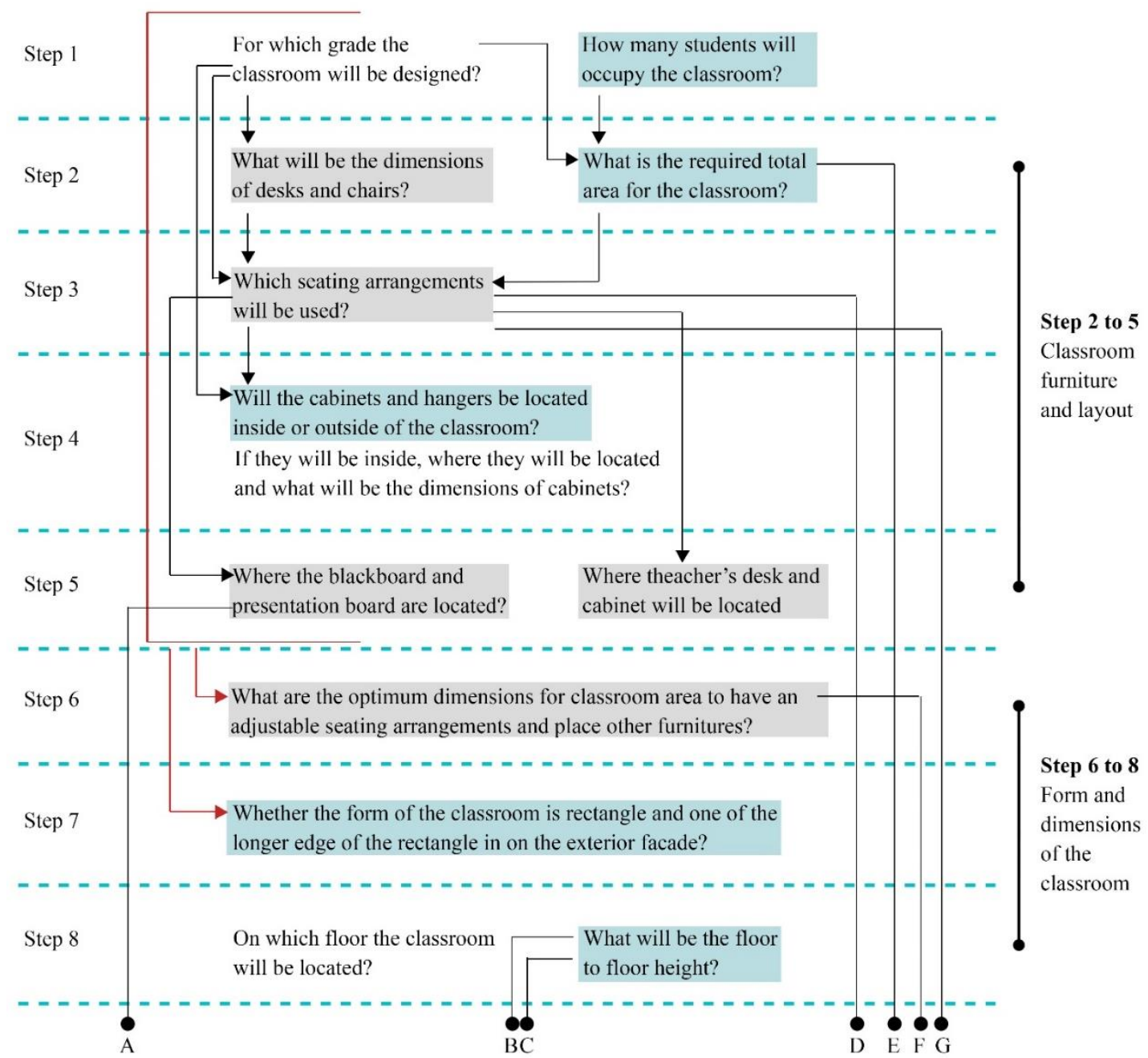

Fig 6. Summary of suggested flow 
Fig.6. Cont'd

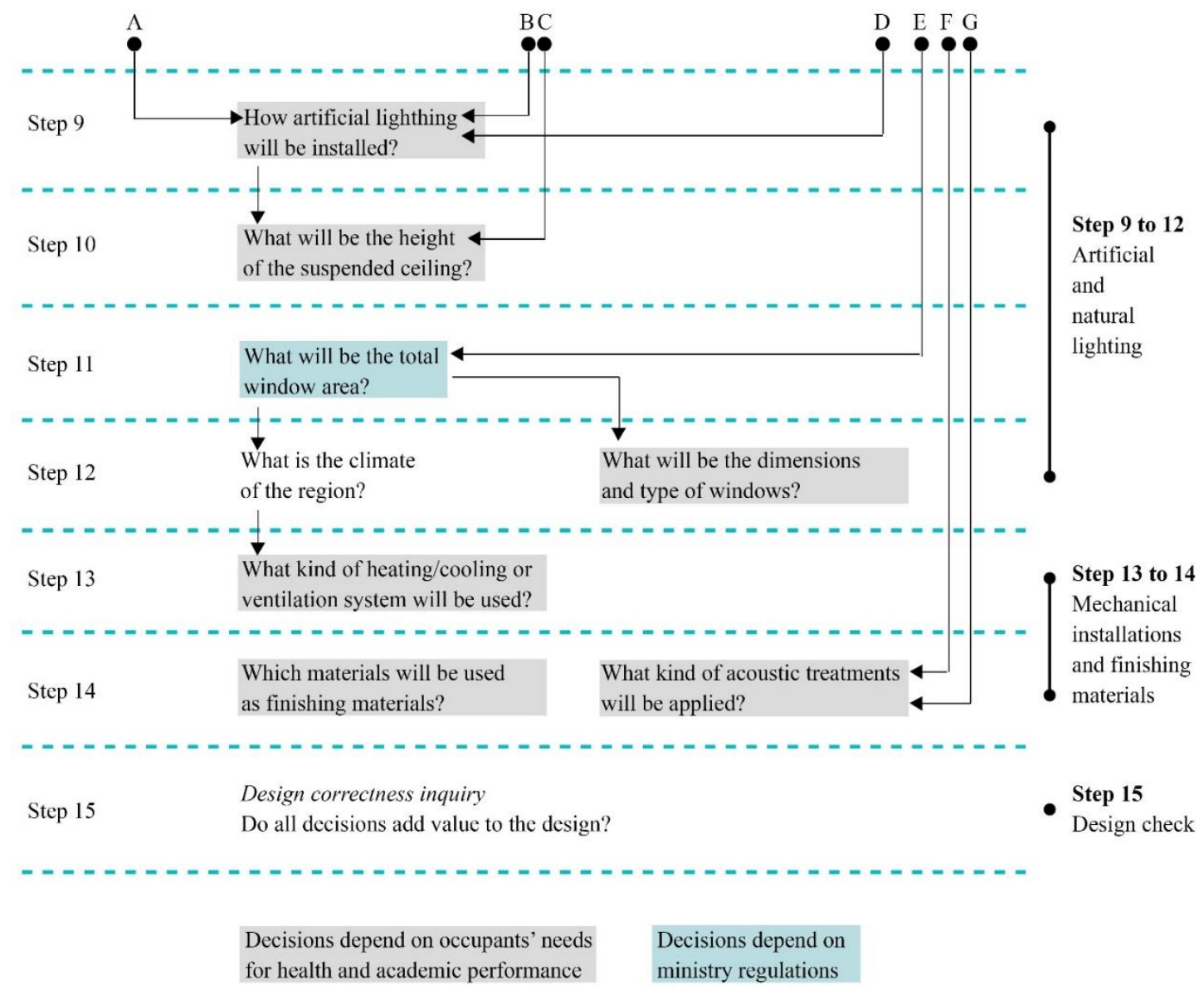

Step 7: The form of the classroom will be a rectangle by selected dimensions, and one of the longer edges is on the exterior façade.

Step 8: The classroom will be on the ground floor, and the floor to floor height will be 3.5 meters.

Step 9: Artificial lighting will be located on the intersection of row and columns and horseshoe seating arrangements and will not interfere with the projector.

Step 10: Suspended ceiling height will be $50 \mathrm{~cm}$, floor to ceiling height will be 3 meters.

Step 11: Total window area will be $12 \mathrm{~m}^{2}$.

Step 12: The school will be in a cold-arid climate. Windows will face to the south; they will be located to provide daylight for the area that is occupied by the desks and prevent glare on the board. No sun breakers will be used for passive solar heating.
Step 13: Heating and ventilation system will be designed for the cold-arid climate.

Step 14: Finishing materials and acoustic treatments will be considered.

Step 15: Suggested inquiry will be used to check design correctness before finishing the preliminary design stage.

The following 3D drawings illustrate the exemplary case. Fig. 7 shows the column and row seating arrangement, students' cabinets, hangers, and pinboards. Fig. 8 shows the windows, teachers' tables, and cabinets.

\section{Conclusion}

Classrooms, having an undeniable effect on the health and education of children, are important spaces that must be designed cautiously. 


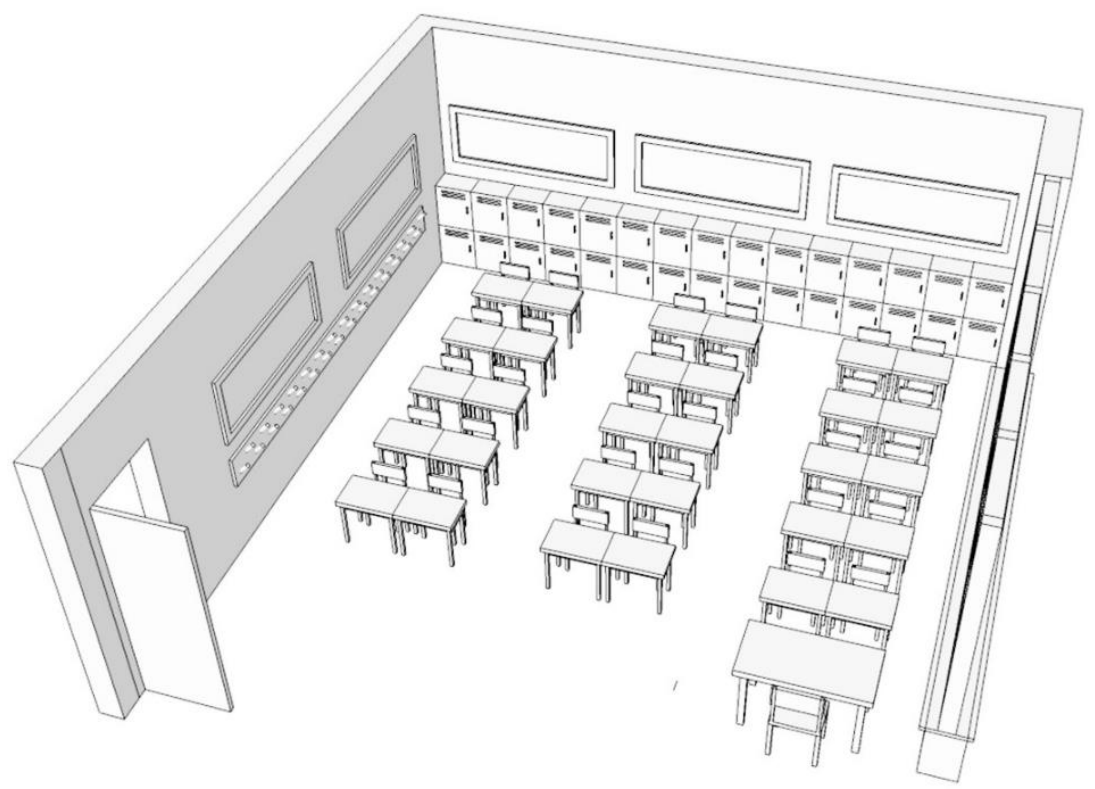

Fig. 7. Column and row seating arrangement, students' cabinets, hangers and pin boards

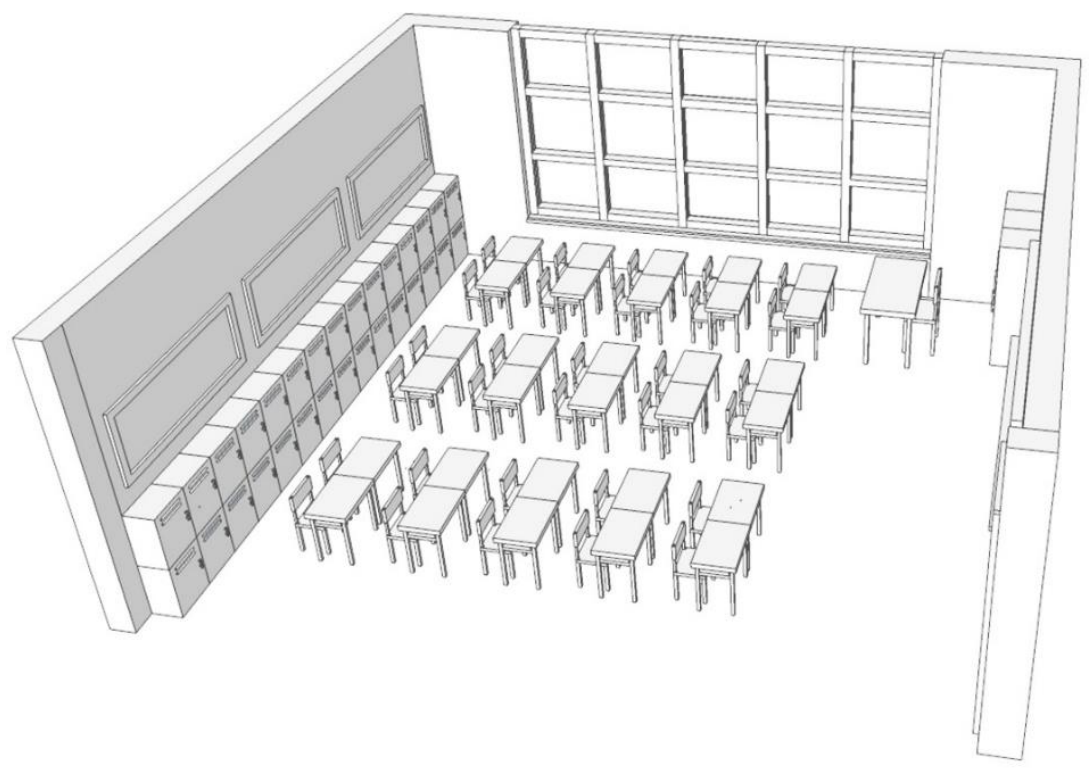

Fig. 8. Windows, teachers' table, and cabinets

In this study, a literature survey is provided to identify important factors for classroom design, and a methodology is suggested for classroom design by applying lean thinking principles; conversion, value, and flow. The paper aims to guide designers to increase value, eliminating mistakes, and providing time efficiency. The methodology starts from the smallest components of the classroom, which are desks and chairs because almost all of the design decisions depend on the students' location and orientation in the classroom. The following steps are constructed in a way to eliminate drawbacks in the design process as possible. On every step, critical concerns, user demands, and necessitates are explained. An inquiry is suggested to evaluate design correctness. Finally, an 
exemplary case is provided in which the suggested methodology is applied.

Instead of studying school buildings as a whole, the study focuses on the classrooms. The content of the study is limited to K12 classrooms. In addition to universal design principles, regulations of the Ministry of National Education of Turkey are also included.

Regardless of the scale and type of the project, any architectural design process consists of interrelated decisions. A variety of possible decisions mostly depends on the function and scale of the project. A project may include infinitely many likely preferences as a result of the subjective perspective of the occupants. However, this is not the case for school projects or K12 classroom design. K12 classrooms must have the same standards in every school all over the country. All children have the same rights regarding education. In Turkey, K12 classroom design is partially regulated by the Ministry of Natural Education. Also, studies from different countries indicate that, regardless of the country or region, occupants' needs and demands show similarity for a classroom environment. It is possible to define universal standards for an ideal classroom environment. Therefore, K12 classroom design is a process that can be standardized and can be executed via a systematic methodology. The main motivation of the study is defining such a systematic methodology that can guide designers, expedite the design process, improve quality, and eliminate mistakes. The main contribution of the study is, introducing the lean thinking principles to classroom design to cope with all the information systematically and define the aforementioned systematic flow.

The study has been started before the COVID19 pandemic. Future studies may investigate how social distance and sanitary precautions can be integrated into the classroom environment and design process.

\section{Declaration of conflicting interests}

The author(s) declared no potential conflicts of interest with respect to the research, authorship, and/or publication of this article.

\section{References}

[1] Sztejnberg A, Finch EF (2006) Adaptive use patterns of secondary school classroom environments. Facilities 24(13/14): 490-509.

[2] Benedict ME, Hoag J (2004) Seating location in large lectures: are seating preferences or location related to course performance?. The Journal of Economic Education 35(3): 215-231.

[3] Ahrentzen S, Evans GW (1989) Architects and school children: in touch or out of focus?, Arch. \& Comport./Arch. Behav. 5(1): 17-28

[4] Chung JWY, Wong TKS (2007) Anthropometric evaluation for primary school furniture design. Ergonomics 50(3): 323-334.

[5] Panagiotopoulou G, Christoulas K, Papanckolaou A, Mandroukas K (2004). Classroom furniture dimensions and anthropometric measures in primary school. Applied ergonomics 35(2): 121128.

[6] O'Hare M (1998) Classroom design for discussionbased teaching. Journal of Policy Analysis and Management 17(4): 706-720.

[7] Marlowe J, Koonce J, Lee J, Cai Y (2006) An examination of the impact of student's work time on academic performance. Consumer Interests Annual 48: 1-9.

[8] Perkins KK, Wieman CE (2005) The surprising impact of seat location on student performance. The Physics Teacher 43: 30-33.

[9] Holliman WB, Anderson HN (1986) Proximity and student density as ecological variables in a college classroom. Teaching of Psychology 13: 200-203.

[10] Koskela L (1992) Application of the new production philosophy to construction. CIFE Technical Report 72, CIFE, Stanford University, Stanford, CA. pp. 4-10.

[11] Hansen GK, Olsson NO (2011) Layered projectlayered process: lean thinking and flexible solutions. Architectural Engineering and Design Management 7(2): 70-84.

[12] Freire J, Alarcón LF (2002). Achieving lean design process: Improvement methodology. Journal of Construction Engineering and management 128(3): 248-256.

[13] Ballard G, Koskela L On the agenda of design management research. In Proceedings of the 6th annual conference of the International Group for Lean Construction. 13 August 1998, pp. 56-69.

[14] Leite KP, Neto D (2013). Value stream in housing design. In 21th Annual Conference of the 
International Group for Lean Construction, Fortaleza, pp. 419-428.

[15] Ko CH, Chung NF (2014). Lean design process. Journal of Construction Engineering and Management, 140(6): 04014011.

[16] Floyd W, Ward J (1964). Posture of school children and office workers. In: Proceedings of the 2nd International Congress on Ergonomics, Dortmund, pp. 351-360.

[17] Castellucci HI, Arezes PM, Molenbroek JFM (2015) Equations for defining the mismatch between students and school furniture: A systematic review. International Journal of Industrial Ergonomics 48: 117-126.

[18] Cooper PJ, Simonds CJ Communication for the Classroom Teacher, Pearson Education Inc., Boston, MA, 2003.

[19] Richmond VP, McCroskey JC,.Nonverbal Behavior in Interpersonal Relations, Allyn and Bacon, Boston, MA. 2000

[20] McCroskey JC, McVetta RW (1978) Classroom seating arrangements: instructional communication theory versus student preferences. Communication Education 27: 99-111.

[21] Scott-Webber, L. In Sync: Environmental Behavior Research and the Design of Learning Spaces, Society for College and University Planning, (SCUP), Ann Arbor, MI, 2004

[22] Choi S, Guerin DA, Kim HY, Brigham JK, Bauer, $T$ (2014). Indoor Environmental Quality of Classrooms and Student Outcomes: A Path Analysis Approach. Journal of Learning Spaces, 2(2): 2013-2014.

[23] Jago E, Tanner K. Influence of the school facility on student achievement: Lighting; color. Athens, GA: Dept. of Educational Leadership, University of Georgia, 1999

[24] Earthman GI. Prioritization of 31 criteria for school building adequacy. Baltimore: American Civil Liberties Union Foundation of Maryland, 2004.

[25] Daisey JM, Angell WJ, Apte MG (2003). Indoor air quality, ventilation and health symptoms in schools: An analysis of existing information

[26] Cash CS (1993). Building condition and student achievement and behavior. Unpublished doctoral dissertation. Virginia Polytechnic Institute and State University, Blacksburg, VA

[27] Mendell MJ, Heath GA (2005). Do indoor pollutants and thermal conditions in schools influence student performance? A critical review of the literature. Indoor Air, 15, pp. 27-52.
[28] Milli Eğitim Bakanlığı. Eğitim Yapıları Asgari Tasarım Standartları 2015 Yı1ı Kılavuzu. Milli Eğitim Bakanlı̆̆ı, Ankara, Türkiye, 2015. 